\title{
STANDARDIZATION OF VITAMIN E
}

$\mathrm{I}^{\mathrm{F}}$ war had not broken out, it was intended by the Health Organisation of the League of Nations to hold a third meeting of the International Conference on Vitamin Standardisation, in preparation for which the Vitamin E Sub-Committee of the Accessory Food Factors Committee (Lister Institute and Medical Research Council), at the request of the Health Organisation, set on foot a co-operative study of $d l-\alpha$-tocopheryl acetate as a possible international standard for vitamin $\mathrm{E}$. It has in the interval been decided that it would be more accurate to use the name synthetic racemic tocopheryl acetate, and this will be done in future.

A supply of the substance sufficient for extensive biological and stability tests, and to provide a standard should the substance ultimately be adopted, was very kindly provided by Messrs. Hoffmann-La Roche of Basle, through the British associated company, Messrs. Roche Products, Ltd., Welwyn Garden City.

Workers in Europe and the United States experienced in vitamin $\mathrm{E}$ tests were invited to participate, and solutions were prepared by Dr. P. Hartley and issued to seventeen laboratories. The workers were asked to test four solutions of the tocopheryl acetate of graded strengths, the proportion in which the series was graded being stated, but no indication being given of the identities of the numbered solutions corresponding with the different strengths.

The object of the test was to obtain the relation between dosage and response, the response used being the fertility-rate defined as the percentage of positively mated female rats which produced a litter. Vitamin $\mathrm{E}$ deficiency is a condition which in an individual animal is not cured ina smoothly graduated selies of stages ; for statistical purposes the response is treated as of an all or none, not of a graded, type. However, the dosage response relation can, as is usual in such cases, be transferred into a linear one by plotting the normal equivalent deviation (or probit) of the percentage response against the logarithm of the dose.

Arrangements were made whereby the stability of the feeding solutions after the tests and of the original material after keeping was tested spectrophotometrically by Dr. R. A. Morton, who reported that the stability of all the materials was entirely satisfactory.

Thirteen of the seventeen laboratories invited completed the biological tests and sent in reports which were submitted to Dr. J. O. Irwin and Dr. E. J. Williams, then at Cambridge, for statistical analysis. In four of the laboratories the slope of the dosage-response curve proved not to differ significantly from zero; in other words the responses to the graded doses were not themselves significantly graded. No determination of the median fertility dose could therefore be made, and the results did not lend themselves to further statistical analysis. For the remaining nine laboratories such a study could be made and the results are summarized in the accompanying table.

\begin{tabular}{|c|c|c|c|c|c|c|}
\hline \multirow{2}{*}{ Laboratory } & \multirow{2}{*}{$\begin{array}{l}\text { No.of } \\
\text { rats } \\
\text { used }\end{array}$} & \multirow{2}{*}{$\begin{array}{l}\text { Slope of } \\
\text { probit/ } \\
\text { log dose } \\
\text { line }\end{array}$} & \multirow{2}{*}{\begin{tabular}{|c|} 
Standard \\
error \\
of slope
\end{tabular}} & \multirow{2}{*}{$\begin{array}{c}\text { Median } \\
\text { fertility } \\
\text { dose } \\
\text { (mgm.) }\end{array}$} & \multirow{2}{*}{\multicolumn{2}{|c|}{$\frac{\text { Limits of error }}{95 \%}-\frac{99 \%}{9}$}} \\
\hline & & & & & & \\
\hline $\begin{array}{ll}1 & \\
2 & (a) \\
& (b)\end{array}$ & $\begin{array}{l}83 \\
40 \\
42\end{array}$ & $\begin{array}{l}5 \cdot 17 \\
5 \cdot 34 \\
7 \cdot 00\end{array}$ & $\begin{array}{l}1 \cdot 09 \\
1 \cdot 42 \\
1 \cdot 73\end{array}$ & $\begin{array}{l}0 \cdot 56 \\
0 \cdot 55 \\
0 \cdot 66\end{array}$ & $\begin{array}{l}86-117 \\
82-123 \\
85-118\end{array}$ & $\begin{array}{l}82-122 \\
77-131 \\
80-125\end{array}$ \\
\hline $\begin{array}{ll}3 & \\
4 & \\
5 & \\
6 & (a) \\
& (b)\end{array}$ & $\begin{array}{l}91 \\
68 \\
48 \\
79 \\
50\end{array}$ & $\begin{array}{l}3 \cdot 60 \\
2 \cdot 63 \\
9 \cdot 23 \\
6 \cdot 83 \\
5 \cdot 07\end{array}$ & $\begin{array}{l}0 \cdot 99 \\
0.96 \\
3 \cdot 35 \\
1 \cdot 32 \\
1 \cdot 30\end{array}$ & $\begin{array}{l}0 \cdot 66 \\
0 \cdot 72 \\
0.84 \\
1 \cdot 13 \\
1 \cdot 14\end{array}$ & $\begin{array}{l}72-139 \\
58-172 \\
85-117 \\
88-114 \\
82-123\end{array}$ & $\begin{array}{l}65-155 \\
49-204 \\
81-123 \\
85-118 \\
77-131\end{array}$ \\
\hline $\begin{array}{ll}7 & \\
8 & (a) \\
& (b) \\
9 & \end{array}$ & $\begin{array}{l}78 \\
52 \\
52 \\
58\end{array}$ & $\begin{array}{r}5 \cdot 52 \\
5 \cdot 89 \\
11.55 \\
6 \cdot 53\end{array}$ & $\begin{array}{l}1 \cdot 03 \\
1 \cdot 48 \\
3 \cdot 17 \\
1 \cdot 62\end{array}$ & $\begin{array}{l}1 \cdot 36 \\
1 \cdot 50 \\
1 \cdot 05 \\
1 \cdot 71\end{array}$ & $\begin{array}{l}87-116 \\
85-117 \\
90-112 \\
84-119\end{array}$ & $\begin{array}{l}83-121 \\
81-123 \\
86-116 \\
80-125\end{array}$ \\
\hline $\begin{array}{c}\text { Means and } \\
\text { errors } \\
\text { Total }\end{array}$ & 689 & $4 \cdot 989$ & $0 \cdot 383$ & $0 \cdot 986$ & $78-128^{*}$ & $72-139^{*}$ \\
\hline
\end{tabular}

$2(a)$ and $(b)$. Ratio of 4 doses the same in each case, but bigger absolute dose given in $2(b)$.

$6(a)$ and $(b)$ Virgins used in $6(a)$; rats which had resorbed in $6(b)$.

$8(a)$ and $(b)$ Criterion in $8(a)$ birth of at least one living young one; eriterion in $8(b)$ birth of at least one young one, living or dead. Rats used in $8(a)$ same as in $8(b)$.

* This error includes error due to inter-laboratory difference.

The table shows the number of rats used by each worker, the slope of the probit/log. dose line, the median fertility dose and the limits of error for each worker's result. The median fertility dose is that dose which enables 50 per cent of the rats used to bear a litter. The results have been arranged in the table to show the variation in size of the median fertility dose, from $0.56 \mathrm{mgm}$. synthetic racemic tocopheryl acetate in the first laboratory, to 1.71 $\mathrm{mgm}$. in the last laboratory, the average value being almost exactly one milligram. The reasons for the variation will be discussed when a fuller report is made, but it is interesting to note that the size of the median fertility dose varied in laboratory 2 in two separate tests, and in laboratory 8 when the definition of a litter was varied so as to require the inclusion of at least one living young one in the litter. These observations of the great variation in the size of the median fertility dose add further evidence, if that were needed, of the necessity for establishing an international standard for vitamin $\mathrm{E}$ so long as biological tests are needed.

The accuracy of the biological technique, as evidenced by the limits of error, seems to be about the same as that usually found with vitamins for a biological method which has been fully elaborated and in use for some time, and the whole co-operative study affords a satisfactory basis for recommending that synthetic racemic tocopheryl acetate should be adopted as international standard for vitamin $\mathrm{E}$.

The workers who took part were: A. L. Bacharach, Glaxo Laboratories, Greenford, Middlesex; A. Z. Baker and M. D. Wright, Vitamins Ltd., Hammersmith, London, W.6; F. Bergel, Roche Products Ltd., Welwyn Garden City, Herts.; A. M. Copping Lister Institute, London, S.W.1; K. H. Coward and B. G. E. Morgan, Pharmaceutical Society, 17 
Bloomsbury Square, London, W.C.1 ; V. Demole and H. M. Wüest, F. Hoffmann-La Roche and Co., Basle; H. von Euler, Biokemiska Institutet, Stockholm 6, Sweden; H. M. Evans, University of California, Berkeley, California; P. Hartley, National Institute for Medical Research, Hampstead, London, N.W.3 ; J. O. Irwin, Queens' College, Cambridge ; B. C. P. Jansen, University of Amsterdam, Laboratory of Physiological Chemistry, Jon. Dan. Meijerplein 3, Amsterdam, Holland ; C. Kennedy and L. S. Palmer, University of Minnesota, Department of Agriculture, University Farm, St. Paul, Minn.; K. E. Mason and W. L. Bryan, Department of Anatomy, Vanderbilt University School of Medicine, Nashville, Tenn. ; H. A. Mattill, Department of Chemistry, State University of Iowa, Iowa City; T. Moore, Dunn Nutritional Laboratory, Milton Road, Cambridge; R. A. Morton, Department of Physical and Inorganic Chemistry, The University, Liverpool ; A. R. Todd, Department of Chemistry, The University, Manchester, 13 ; S. W. F. Underhill, British Drug Houses Ltd., Graham Street, City Road, London, N.1 ; E. J. Williams, Forest Products Research Laboratory, Melbourne, Victoria.

\section{E. M. HuME.}

(Secretary, Vitamin E Sub-committee of Accessory Food Factors Committee, appointed by Lister Institute and Medical Research Council.)

Lister Institute,

London, S.W.1.

\section{AN INTERNATIONAL Standard For Vitamin E}

It is now announced that an international standard for vitamin $\mathrm{E}$ has been established and that, as in the case of the international standards for the vitamins $A, B_{1}, C$ and $D$, the National Institute for Medical Research, Hampstead, London, N.W.3, acting on behalf of the Health Organization of the League of Nations, has undertaken its supply to laboratories, institutes and research workers, throughout the world.

Synthetic racemic $\alpha$-tocopheryl acetate $\left(\mathrm{C}_{31} \mathrm{H}_{52} \mathrm{O}_{3}\right)$ has been adopted as the international standard for vitamin $\mathrm{E}$. The investigation of the chemical, physical and biological properties of this substance, its suitability for adoption as the international standard, and the manner of its application in biological assay was carried out, at the request of the Health Organisation of the League of Nations, by the Vitamin E Sub-Committee of the Accessory Food Factors Committee of the Lister Institute and the Medical Research Council. The sub-Committee was able to enlist the co-operation of experts in laboratories in Europe and the United States, and, as a result, it was able to recommend the adoption of synthetic racemic $\alpha$-tocopheryl acetate as the international standard for vitamin $\mathbf{E}$. The SubCommittee further recommended that the international unit for vitamin $\mathrm{E}$ should be defined as the specific activity of $1 \mathrm{mgm}$. of the standard preparation, this quantity being the average amount which, when administered orally, prevents resorptiongestation in rats deprived of vitamin $\mathrm{E}$.

In normal circumstances the results of the cooperative investigation would have been submitted for discussion at the Third International Conference on Vitamin Standardisation, which had been arranged for the autumn of 1939. On account of the War this Conference could not be held. The report and recommendations of the Sub-Committee have, however, been placed before those members and officers of the League of Nations' Permanent Commission on Biological Standardisation and of the International Conference on Vitamin Standardisation, who were available and accessible, and these consented to accept the responsibility of taking such decisions as would normally be accepted by a properly constituted International Conference and by the Permanent Commission. They have accordingly adopted the proposed standard for vitamin E, accepted the recommendation defining the international unit, and authorized the National Institute for Medical Research, Hampstead, to proceed with the distribution of the standard.

The international standard for vitamin $\mathrm{E}$ is issued in the form of a solution in olive oil of which one international unit is contained in $0.1 \mathrm{gm}$. It will be supplied to directors of national control centres in those countries in which these have been established, for local distribution; also to laboratories, institutes and research workers in Great Britain, and in those countries in which national control centres have not yet been established. Application should be made to the Department of Biological Standards, National Institute for Medical Research, Hampstead, London, N.W.3.

\section{PSYCHOLOGICAL HANDICAPS IN THE SEARCH FOR TRUTH}

\section{By DR. J. Hettinger}

$\mathrm{T}$ HERE are three main psychological factors which handicap the mind in its search for truth, irrespective of the nature of the subject. They are :

(1) The limitations of the field of mental vision ;

(2) Our personal mental worlds ; and

(3) Our lack of knowledge of the true relationships between all existing realities and, accordingly, lack of unity in our personal mental worlds in correspondence with the unity reigning in the universe.

\section{(I) Limitations of the Field of Mental Vision}

All forms of sensory perception have their respective limits, for example, as regards space, time, clearness, intensity, etc.; purely intellectual perception, such as we experience in mental contemplation and meditation, and which may be referred to as 'mental vision', extends over a field which has its own specific limits.

The first limitation of the field of mental vision is determined by the amount of knowledge we have 